\title{
THE BIOLOGY OF BRACHYPANORPA (MECOPTERA) ${ }^{1}$
}

\author{
By F. M. Carpenter \\ Harvard University
}

The Genus Brachypanorpa, as now known, consists of only three species, all confined to the United States: one in the southern Appalachian region and two in the northwestern region. The distinctive features of the genus are the absence of the long rostrum characteristic of other Mecoptera and the reduction of the wings in the females. The most closely related genus-and indeed the only one which shows any affinities at all with Brachypanorpa-is Panorpodes, known only from Japan. The species of the latter, however, possess a distinct rostrum and fully developed wings in both sexes.

Virtually nothing has been known of the general biology of either of these two genera. Japanese entomologists have attempted to rear larvae of Panorpodes, but without success. During the past two years Dr. F. Y. Cheng and I have made observations on the habits of Brachypanorpa carolinensis, both in the field and laboratory, and have been able to work out part of its life-history. The present paper includes our observations on the adults of this insect and brings together some notes on the distribution of all three species of the genus. In another paper Dr. Cheng will give an account of the larva of carolinensis.

\section{Brachypanorpa carolinensis (Banks) ${ }^{2}$}

This species was first taken by William Beutenmüller in the Black Mountains, North Carolina, on May 26, 1903, and was described by Banks in 1905 (as Panorpodes carolinensis) from seven males in Beutenmüller's collection.

${ }^{1}$ Published with a grant from the Museum of Comparative Zoology at Harvard College.

${ }^{2}$ For the nomenclature of Brachypanorpa, see my revision of the Nearctic Mecoptera (Bull. Mus. Comp. Zool., 72:205-277, 1931). 
The exact localities in the Black Mountains at which Beutenmüller found his specimens are not known, but it is clear from a short note published in 1903 that his collecting was done in the southern half of the Black Mountain range. On subsequent trips he took many additional specimens of the species in that range. In late May, 1905, Nathan Banks made a trip to the same region, but most of his collecting was done along the North Fork of the Swannanoa River, ${ }^{3}$ a few miles north of the town of Black Mountain and just east of Craggy Knob, in the Craggy Mountain range. At this locality Banks collected a great many specimens of carolinensis, including the first females. The latter he mentioned in a paper published in 1911, stating that they had very short wings, were unable to fly, and hopped about very lively. Additional females were subsequently taken by Beutenmüller in the Black Mountains.

Other localities for the species were added by R. W. Leiby, who found it abundant near the top of Mt. Mitchell, the highest peak $\left(6700^{\prime}\right)$ in the Black Mountains (July, 1919), and who also collected it in the Craggy Mountains (June, 1920) about six miles from the Black Mountains and only three miles from Banks' locality along the North Fork of the Swannanoa. It was also found by F. Sherman at Linville Falls (4000', late May and June, 1920) in the Blue Ridge Mountains, twenty miles northeast of the Black Mountain range.

So far as I am aware, carolinensis was not collected again for about thirty years, until May, 1951, when Dr. Cheng, Dr. W. Nutting, Dr. K. Christiansen and I secured many specimens at Carolina Hemlock Camp on the edge of the Black Mountains, and brought back alive 150 males and seven females to Cambridge for study. By what is certainly a striking coincidence, at about this same time (May 17, 1951), several specimens were collected by Dr. P. W. Fattig at Unicoi Gap in Georgia (near the town of Robertson). In May, 1952, Dr. Cheng and I again visited the Black Moun-

${ }^{3}$ Banks' labels for this locality read, "Black Mt., North Fork Swannanoa". It should be noted that the town of Black Mountain is not in the Black Mountains, but is about twenty miles south of that range. 
tains. Both sexes of carolinensis were active when we reached Carolina Hemlock Camp on May 15. The males remained abundant until June 1, but the females were numerous only on May 20th. Specimens of both sexes were collected at many places in the Black Mountains, including Cobert Creek, towards Deep Gap; along White Oak Creek; along Laurel Fork, near Busick; along South Toe River towards Bald Knob Ridge; at Potato Knob and Stepp Gap (Beutenmüller's localities). Specimens were also found at Craggy Gardens, in the Craggy Mountains. On May 23, 24 and 25, P. W. Fattig and I found many specimens at Unicoi Gap, at Henson Gap, and on Blue Mountain, Georgia (all between $3600^{\prime}$ and $4000^{\prime}$ elevation).

The history of the collecting of this insect has been given in detail above because it contributes significant evidence to our understanding of a change that seems to have taken place in the female population. As stated above, the females of the three known species of Brachypanorpa have smaller wings than the males (see Plate 2). The real notable aspect of the record of carolinensis is that all of the females (20 specimens) known to me to have been collected from 1903 to 1920 have wings which do not reach to the end of the abdomen (see Plate 2, fig. B) and which were so small in area that the insects (according to Banks) were flightless and could only hop about; whereas all the females (80 specimens) which Dr. Cheng and I collected in 1951 and 1952 at the previous localities, as well as new ones, have wings which extend beyond the end of the abdomen (see Plate 2, fig. C) and which have such an area that the insects were able to fly distances of several feet.

Since the males taken over the entire period show no differentiation and the females exhibit no differences except in wing size, I believe we are dealing here with a single species, the female population of which has under-

Explanation ois Plate 2

Brachypanorpa carolinensis (Banks). A. Drawing of male from Carolina Hemlock Camp, North Carolina. B. Drawing of female from Black Mt., N. Fork of Swannanoa, Norih Carolina (1905). C. Drawing of female from Carolina Hem'ock Camp, North Carolina (1951). All drawings are to scale. 


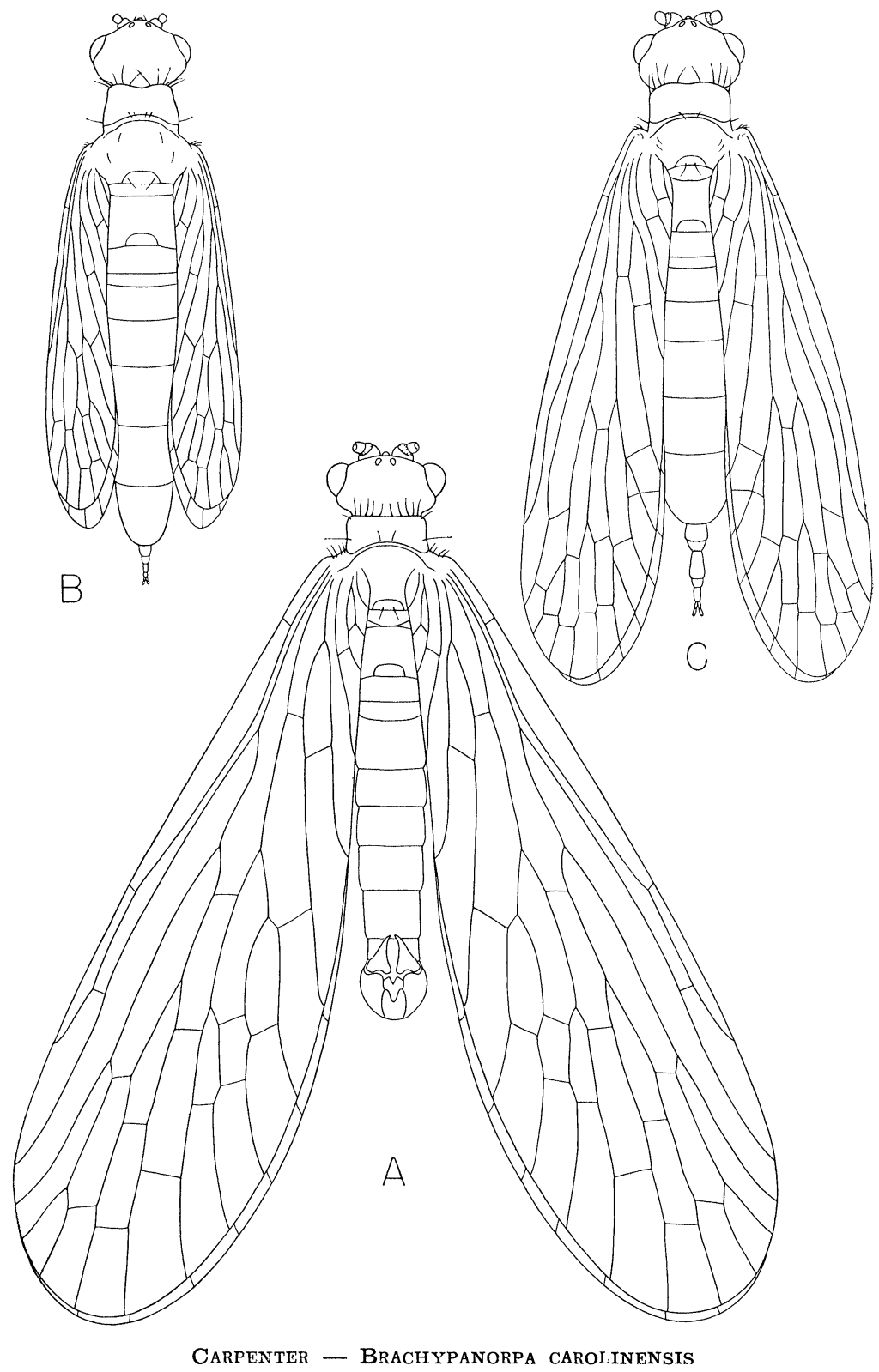


gone a marked change in the past thirty years. Although the long winged females may have been present as a small minority in the population before 1920, they are now clearly the majority in the same population. The reverse applies, of course, to the short winged females. It is conceivable that the long winged females, which are able to fly short distances and which might, therefore, more readily find males, have a definite selective advantage over the flightless females. This could account for such a change taking place in the course of a maximum of 30 generations.

The distribution of carolinensis presents some interesting features. Its most northern record is now Linville Falls, North Carolina, and its most southern near Unicoi Gap, Georgia. The species seems to be confined to the narrow strip of mountainous country, about 120 miles long, between these two places. However, even in this area, the species appears to be local except for the Black Mountains, where it occurs more generally. With the possible exception of one individual (the data on which are questionable), all specimens of the species so far known to me have been collected at elevations between 3000 and 6700 feet. At the lower elevations, as at Carolina Hemlock Camp (3000'), both male and female adults occur as early as May 15, but virtually all disappear by June 4 . At higher elevations (such as 6000'), the adults do not appear until early July; both sexes have been taken as late as July 18 on the top of Mt. Mitchell $\left(6700^{\prime}\right)$.

The species occurs only in shady woods, where the soil is moist, though without any definite plant associations. Galax, Rhododendron, Jack-in-the-Pulpit, jewel weed, asters and May apple occur commonly where carolinensis is found, but these plants are characteristic of nearly all moist woods in the southern Appalachian region. Some of them, however, may be necessary as food for the adults of carolinensis. Our first efforts to keep the adults alive in cages failed completely because we did not find anything on which they would feed. Bits of animal flesh or of dead insects, which Panorpa and Neopanorpa readily consume, were not eaten by carolinensis. Subsequent observation showed that they fed on the epidermis of soft leaves, such as those of aster 
and jewel weed, by scraping the surface of the leaves with their mouth-parts. Caged specimens furnished with fresh leaves lived through the life span of adults in their natural environment.

The males of carolinensis fly much like those of Panorpa, though usually not quite so far. The females, after pupal ecdysis, crawl up the stems of low-growing plants, and spend much of the time on the ventral surface of the leaves. This undoubtedly explains why so relatively few females have been found. When disturbed, the females will fly, usually downward, to another leaf or to the ground. Mating takes place on the leaves, usually on the upper surface. Complicated courtship, like that in Panorpa, is entirely absent; the male quickly approaches and grasps the female with his terminal forceps. Mating usually occurs in the evening, but may take place anytime during the day. A day or two after mating, the female works the tip of her abdomen into the soil and lays a loose mass of white eggs. Details of egg structure and development will be given by Dr. Cheng with his account of the larva.

\section{Brachypanorpa oregonensis (MacLachlan)}

This species was first collected on Mt. Hood, Oregon, in 1881, and was described by MacLachan the same year from males only. The males differ from those of carolinensis chiefly by having several long ocellar bristles, absent in the latter. The females, first described by Carpenter (1931), are flightless, the wings being only as long as the thorax (Text fig. 1B).

$B$. oregonensis has now been found at many localities in the western half of Oregon, in the area extending nearly the full width of the state and about 130 miles inland from the coast. Unlike carolinensis, which has been found only at relatively high elevations, oregonensis occurs all the way from about sea-level (e.g., Glenada and Walport) to as high as 7000 feet at Crater Lake. Also the seasonal range of the adults is much greater than for carolinensis. At relatively low elevations (up to $1000^{\prime}$ ), the adults have been found from April 20 to June 22; at higher elevations $\left(3000-7000^{\prime}\right)$, from June 19 to August 4. Although there 
are no observations on the occurrence of oregonensis over a period of several weeks at any one locality, the foregoing records suggest either a longer period of adult life than in carolinensis or a greater seasonal period of emergence from the pupae.

A few specimens of this insect have been found outside the state of Oregon. One male (now in the Museum of Comparative Zoology) was collected on the northern Californian coast (Patrick's Point State Park, Humboldt Co., June 2, 1950, W. L. Nutting and F. Werner) ; another (in the California Academy of Sciences) was taken in northern Idaho, almost at the Canadian border (Coolin, Priest Lake, July 15, 1927, E. C. Van Dyke. ${ }^{4}$ The most surprising record is a male (in the U. S. National Museum) from eastern Utah (Neola, near Vernal, July 13, Harmston). A more extensive series of specimens of Brachypanorpa from these northwestern states may show that more than one species is involved in this population, though structural details of both sexes seem notably constant.

\section{Brachypanorpa montana Carp.}

This species was originally based on nine males from Mt. McLoughlin, Klamath Co., Oregon, 8000-9000 feet elevation (July 19, 1930, H. A. Scullen). They were specifically separated from oregonensis chiefly on their darker color, since the males of Brachypanorpa, like those of Panorpodes (Japan), appear to show no marked structural differences between species. Subsequent examination of more specimens of Brachypanorpa from Oregon convinced me that the coloration was not a reliable characteristic and that montana was a synonym of oregonensis. ${ }^{5}$ Since then a female Brachypanorpa, having a very dark body and wings which extend beyond the abdomen (Text-fig. 1, A), has been collected at Lake of the Woods, Klamath Falls, Oregon

\footnotetext{
${ }^{4} \mathrm{I}$ am indebted to Dr. E. S. Ross for the loan of this specimen.

${ }^{5}$ Records and Notes of Nearctic Mecoptera and Raphidiodea. Bull. Brooklyn Ent. Soc., 34(3):163 (1939).
} 
(5100', July 5, 1946, B. Malkin).$^{6}$ There are several reasons for considering this female a representative of a species distinct from oregonensis; and since it was collected near the type locality of montana, as pointed out by Miss Parfin, I now believe it advisable to re-instate the latter as
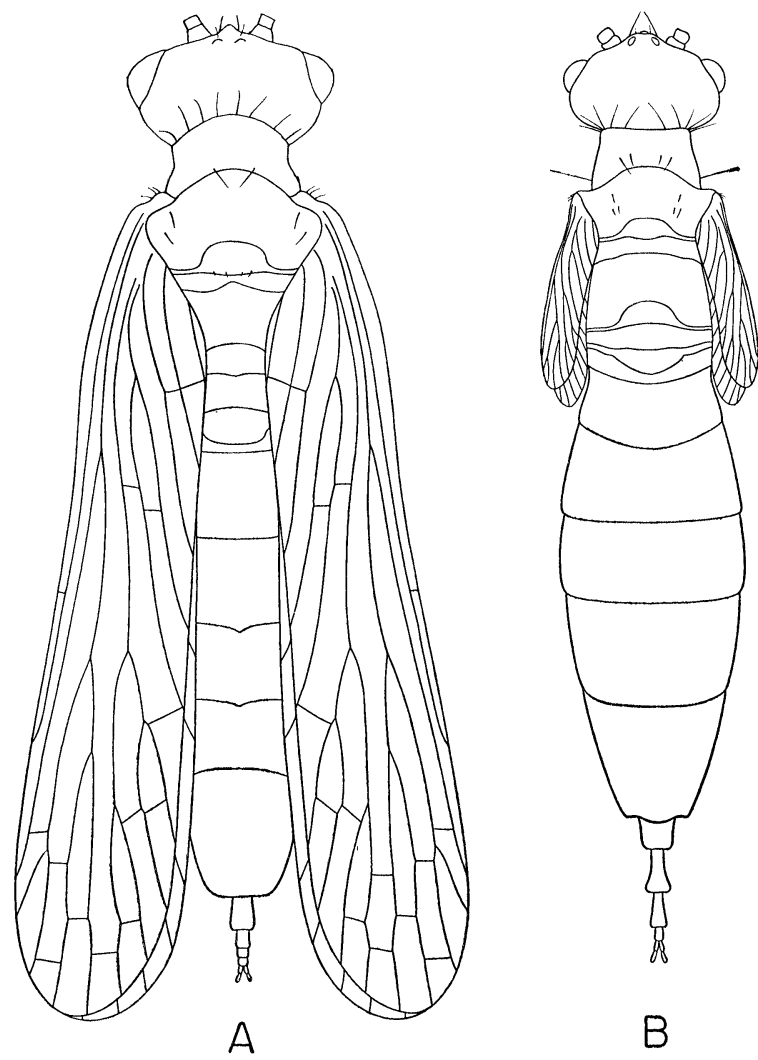

Text-figure 1. A. Brachypanorpa montana Carp., drawing of female from Mt. McLoughlin, Oregon. Actual length of specimen, $8.7 \mathrm{~mm}$. B. Brachypanorpa oregonensis (McLach.), drawing of female from Mary's Peak, Oregon. Both drawings are to scale.

${ }^{6}$ I am indebted to the U. S. National Museum for the loan of this specimen, which was briefly noted by S. Parfin (Proc. Ent. Soc. Washington, 49:258, 1947). 
a valid species and tentatively to assign this female there. Additional collecting, or better still, rearing experiments, will undoubtedly clarify the relationship of this female, of the males described as montana, and of oregonensis. The most interesting aspect of this female, and my reason for mentioning it here, is its analogy with the long winged females of carolinensis, described above. There clearly exist or have existed in both the eastern and western populations of Brachypanorpa long winged and short winged females. The collecting data on carolinensis, given in some detail above, suggest that the long winged female is now the dominant, if not the only, form in existence in the eastern population. Comparable data on the western females have not been obtained, but I believe the occurrence of even the single long winged female shows that a similar genetical trend, (i.e., towards the development of both short winged and long winged females) has existed in both populations. More intensive collecting of Brachypanorpa in Oregon, especially at one locality over a whole season, might furnish data indicating even further similarities. 

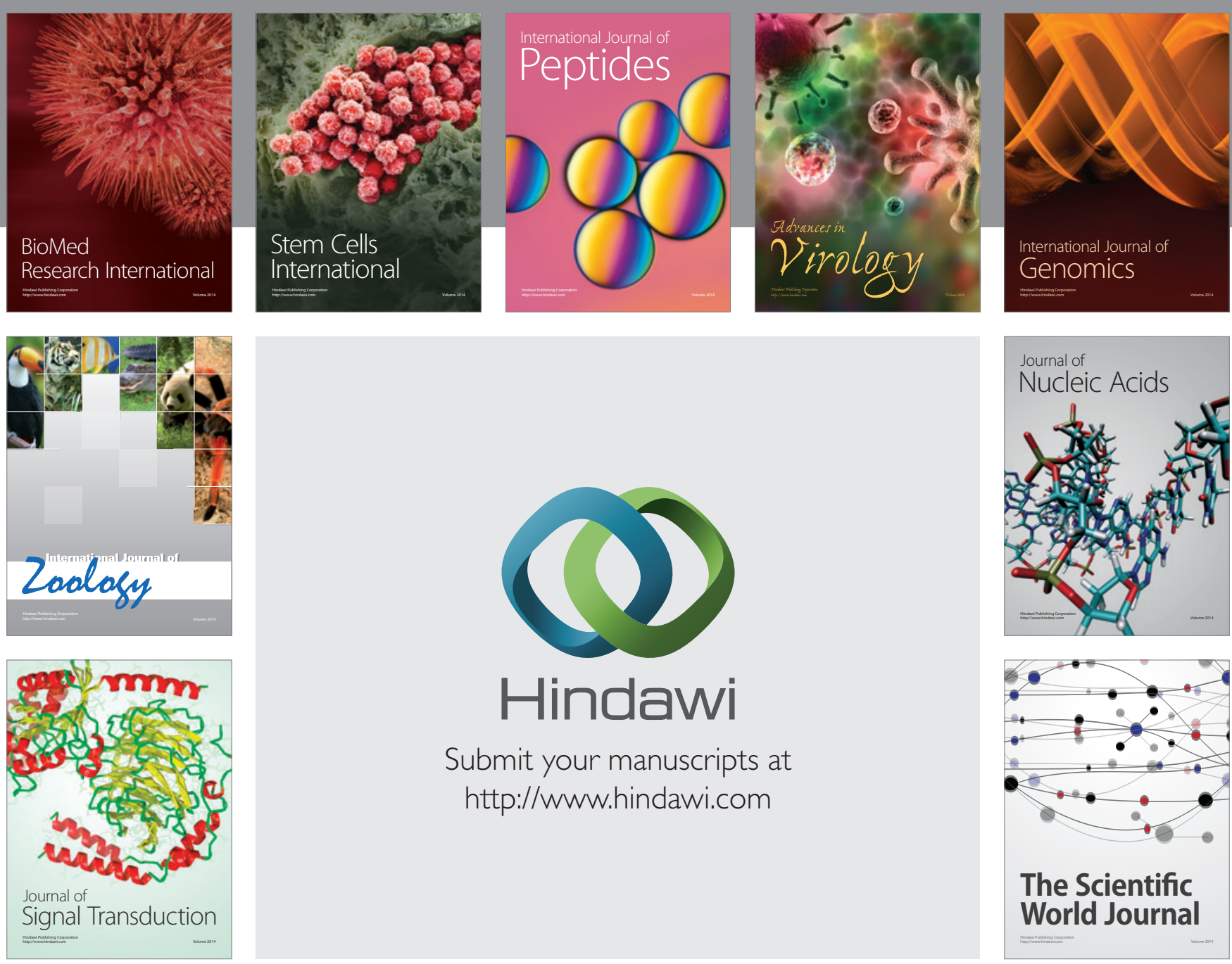

Submit your manuscripts at

http://www.hindawi.com
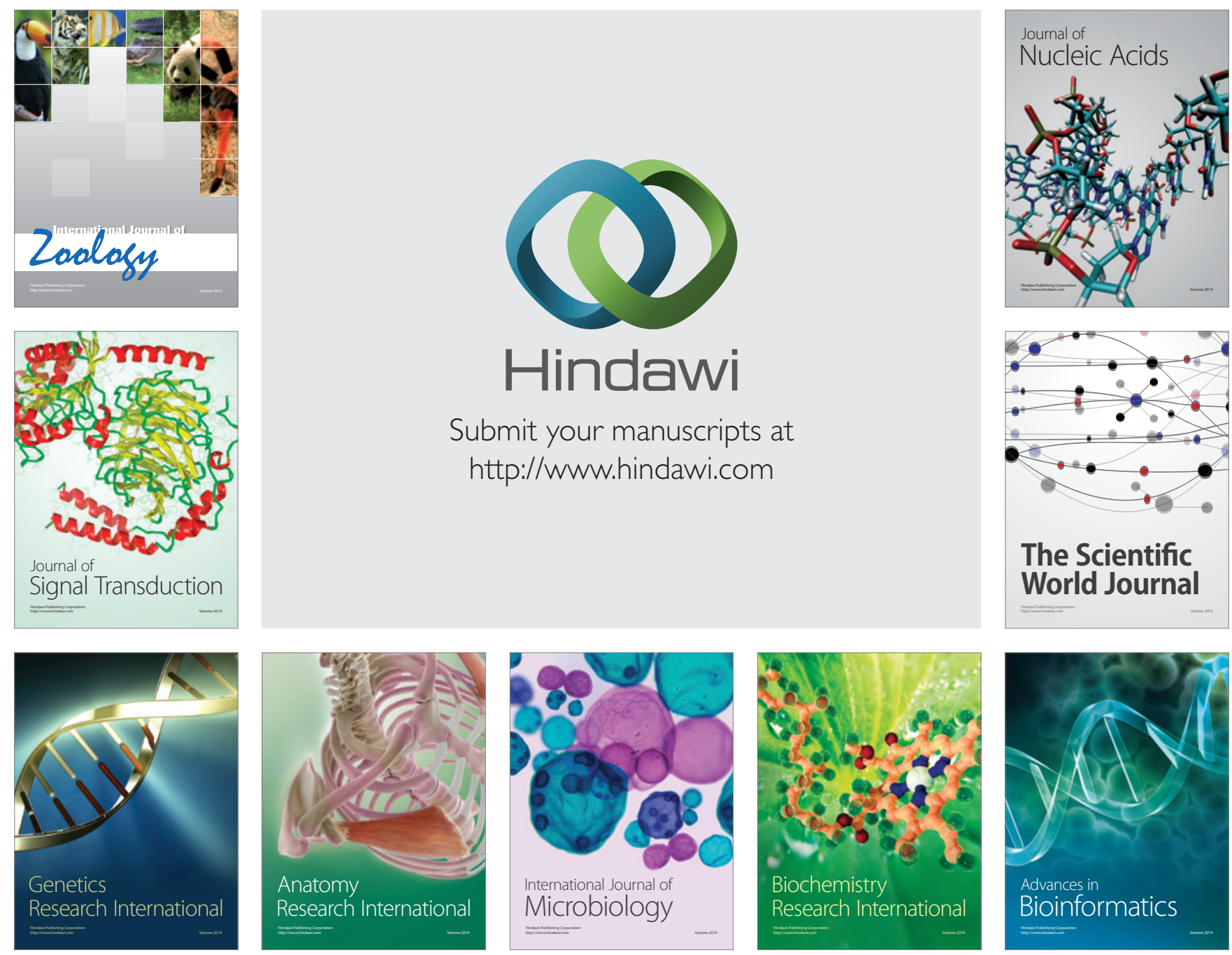

The Scientific World Journal
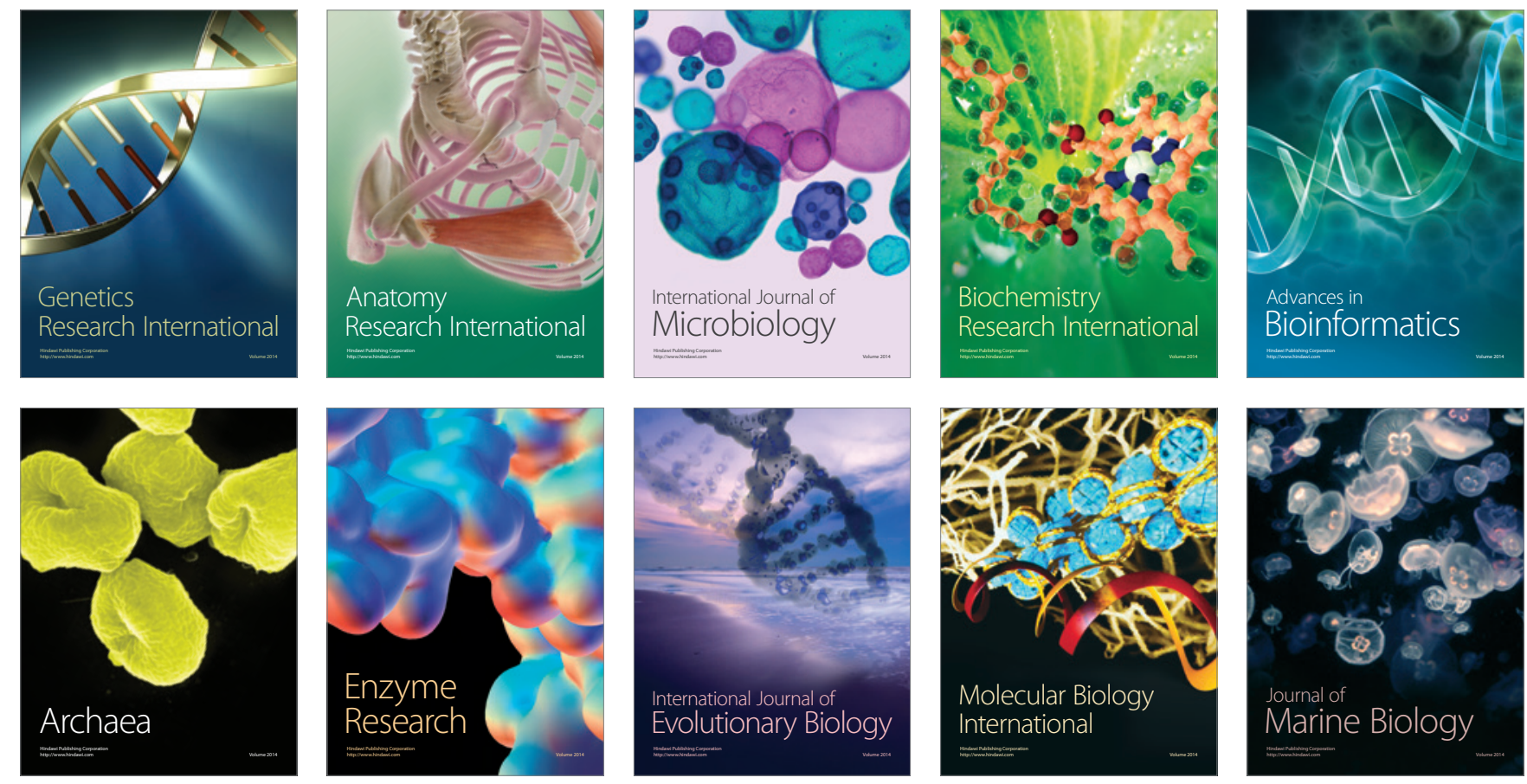